\title{
A new species of Protoptila Banks (Trichoptera: Glossosomatidae: Protoptilinae) from Brazil
}

Allan Paulo Moreira SANTOS ${ }^{1}$, Jorge Luiz NESSIMIAN ${ }^{2}$

ABSTRACT

A new species of Protoptila Banks (Trichoptera: Glossosomatidae: Protoptilinae) - P. longispinata sp. nov. - is described and illustrated from specimens collected in Amazon region, Amazonas and Pará states, Brazil.

KEY WORDS: Amazon basin, Protoptila longispinata sp. nov., Neotropical Region, taxonomy.

\section{Uma nova espécie de Protoptila Banks (Trichoptera: Glossosomatidae: Protoptilinae) do Brasil}

\section{RESUMO}

Uma nova espécie de Protoptila Banks (Trichoptera: Glossosomatidae: Protoptilinae) - P. longispinata sp. nov. - é descrita e ilustrada a partir de espécimes coletados na Região Amazônica, estados do Amazonas e do Pará, Brasil.

PALAVRaS-CHAVE: bacia Amazônica, Protoptila longispinata sp. nov., Região Neotropical, taxonomia. 


\section{INTRODUCTION}

The genus Protoptila currently has 93 described species widespread throughout the Americas, but with most species occurring in the Neotropics (Robertson \& Holzenthal, 2008). This is the largest genus of the subfamily Protoptilinae, represented in Brazil by 12 species, ten of which were described from Amazon basin, nine occurring in Amazonas State: $P$. condylifera Flint, 1971, P. disticha Flint, 1971, P. ensifera Flint, 1971, P. flexispina Flint, 1971, P. mara Flint, 1971, P. simplex Flint, 1971, P. ternatia Flint, 1971, P. tetravittata Flint, 1971, and P. trispicata Flint, 1971, and three (P. disticha, P. macilenta Flint, 1971, and P. simplex) in Pará State (Flint 1971, Paprocki et al. 2004).

Adults of Protoptila are brown in color, have a small size (less than $5 \mathrm{~mm}$ ), and can be collected in large numbers with light traps. Based on material from Amazonas and Pará states, male and female of a new species of Protoptila - P. longispinata sp. nov. - are described and illustrated in this paper.

\section{MATERIAL AND METHODS}

The material was collected with "Malaise" and light traps, and preserved in $80 \%$ ethanol. To observe structures of the male and female genitalia, the abdomens were removed and cleared in $10 \% \mathrm{KOH}$. The illustrations were made under a microscope equipped with a camera lucida. Terminology for male genitalia follows that presented by Holzenthal \& Blahnik (2006), and for female genitalia was adapted from that presented by Schmid (1998). The female association was presumptive, based on the co-occurrence with males. The holotype is deposited in the collection of the Instituto Nacional de Pesquisas da Amazônia, Manaus, Brazil (INPA), and paratypes are deposited in the same institution and also in the Coleção Entomológica Prof. José Alfredo Pinheiro Dutra, Departamento de Zoologia, Universidade Federal do Rio de Janeiro, Rio de Janeiro, Brazil (DZRJ), as indicated in the material examined.

\section{PROTOPTILA LONGISPINATA SP. NOV.}

Figures 1-8

Diagnosis. The new species can be recognized by sternum VIII broad and scoop-like and bearing pair of acute processes on posterolateral margins; by tergum X, in lateral view, with a short dorsal process and ventral margin rounded; and by phallic apparatus with paired, upturned, acute basal processes, and with very long dorsolateral processes.

Description. Male. General color, in alcohol, brown. Length of forewing 2.2-2.6 mm ( $\mathrm{n}=54)$. Antennae stramineous with short dark brown setae. Maxillary palpus covered by short dark brown setae, first and second segments with long dark brown setae on internal surface, and second segment with internal area slightly expanded. Forewings covered by long dark brown setae, and with a light transverse bar at midlength; forks I, II, and III present; discoidal cell closed (Figure 1). Hind wing with forks II and III present (Figure 2); nygma and thyridium inconspicuous in fore- and hind wings. Legs yellowish brown, with short dark setae. Abdominal segments with long dark setae. Sternum VI with a short, slightly curved and subtriangular posteromesal process. Male genitalia. Sternum VIII broad and scoop-like, posterolateral margins with an acute process, and with long setae on all surface (Figure 4). Segment IX not produced posteroventrally, but produced anteroventrally throughout segment VII. Preanal appendages absent. Tergum X, in dorsal view, divided mesally, with lateral lobes curved inward at apex; in lateral view, subtriangular, apically with a short process dorsal and with ventral margin rounded (Figure 3). Phallic apparatus, basally, with pair of short, rodlike articulated appendages with apical setae, and with long, paired, upturned, acute basal processes, and with very long dorsolateral process curved posteriorly and apically acute; endophallus membranous; phalicata esclerite short and slightly esclerotized (Figure 5).

Female. Length of forewing 2.2-2.6 mm $(\mathrm{n}=66)$. Coloration and overall features of head and thorax as in male. Abdominal segments with long dark setae. Sternum VI with a short posteromesal process. Female genitalia. Segment VIII, in ventral view, with long and short setae on mesal area, posterior margin produced into a subtriangular lobe, which have a long apical sclerotized rod produced anteriorly throughout anterior area of segment VII, reaching as membranous tube the anterior area of segment VI (Figure 6); in dorsal view, posterior margin rounded, with slightly internal incision, and bearing long and short setae (Figure 7). Segment IX represented internally by sclerotized plate produced anteriorly into segment VII (Figure 8 ); in ventral view, posterior margin rounded and linked to ventral lobe of segment VIII. Segment X, in dorsal view, divided into 2 lobes with long setae on posterior margin and short setae on all surface; bearing pair of apical papillae (Figure 7). Vaginal sclerite with anterior spindle-shaped opening;
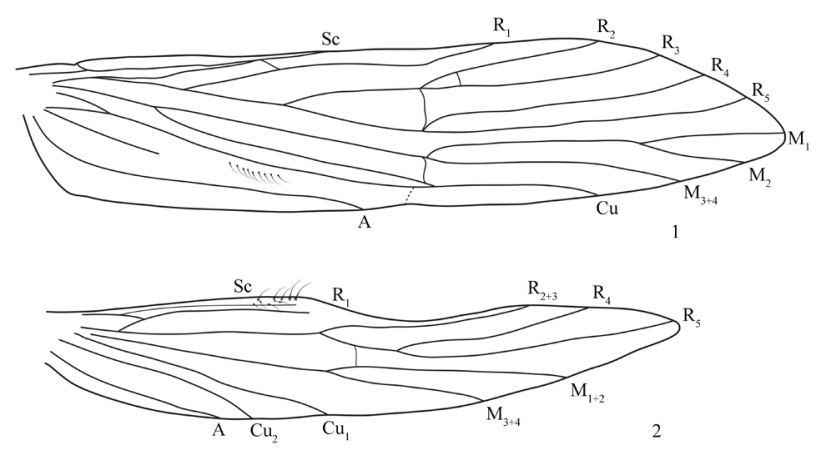

Figures 1-2 - Protoptila longispinata sp. nov.: 1. forewing; 2. hind wing. Bar $=0.5 \mathrm{~mm}$. 

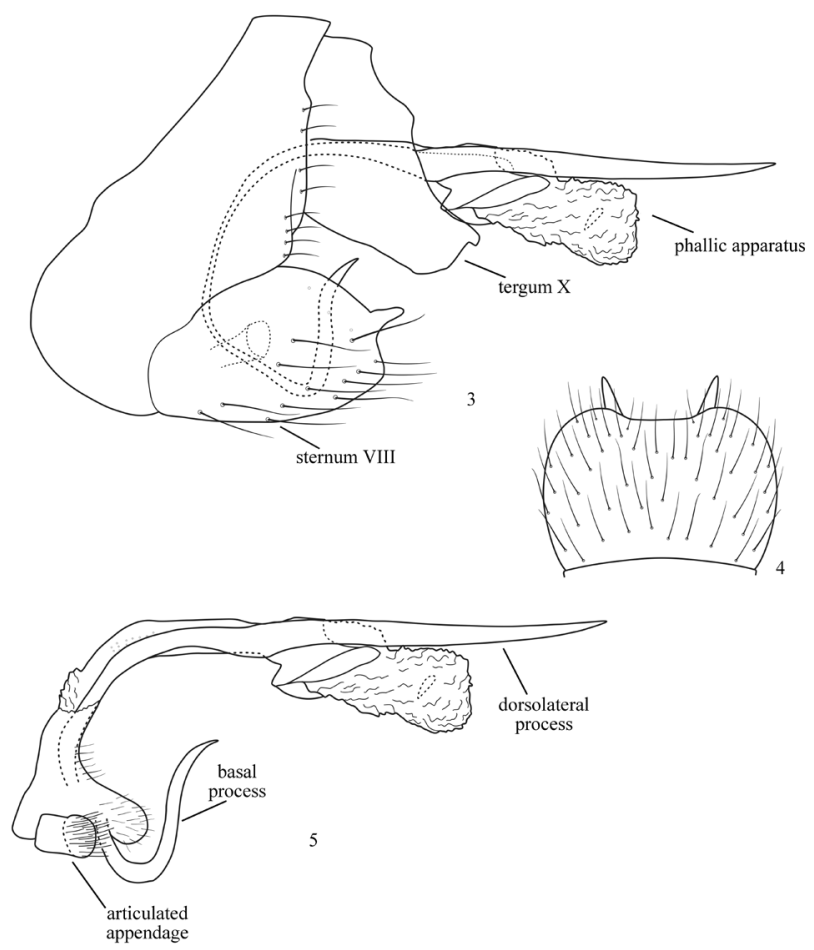

Figures 3-5 - Protoptila Iongispinata sp. nov.: 3. male genitalia, lateral view; 4. sternum VIII, ventral view; 5 . phallic apparatus, left lateral view. Bar $=$ $0.1 \mathrm{~mm}$.

posterior margin with long posterolateral projections and produced mesally into wide lobe (Figure 8).

Holotype male: BRAZIL, Amazonas, Manaus: tributary to Rio Branquinho, 02³1'24.6”S 60²0'05.3”W, 25.viii.2004, J.L. Nessimian \& L. Fidelis leg., light trap (INPA).

Paratypes: BRAZIL, Amazonas, Manaus: same data as holotype, 27 males, 25 female (INPA); tributary to Rio Cuieiras, 02³2'10.0”S 60¹9'01.9”W, 23.viii.2004, J.L. Nessimian \& L. Fidelis leg., light trap, 1 male (DZRJ); Igarapé Arumã, tributary to Rio Cuieiras, 02³0'55.2”S 60¹5'44.4”W, 23.viii.2004, J.L. Nessimian \& L. Fidelis leg., light trap, 1 male (DZRJ); tributary to Rio Branquinho, $02^{\circ} 29^{\prime} 35.1$ "S 60²0'03.1”W, 26.viii.2004, J.L. Nessimian \& L. Fidelis leg., light trap, 16 males, 35 female (DZRJ); Rio Preto da Eva municipality: tributary to Rio Preto da Eva, 02³6'45.5”S 5943'59.1”W, 23.iv.2004, J.L. Nessimian leg., light trap, 5 males, 1 female (INPA); tributary to Rio Urubu, 02³1'01.3”S 5943'13.7”W, 25.iv.2004, J.L. Nessimian leg., light trap, 1 male (DZRJ). Pará, Santarém: Alter do Chão, Igarapé do Heitor, 02³2'22.2”S 5455'53.6”W, J.L. Nessimian, A.M.O. Pes \& L. Fidelis leg., malaise trap, 2 males, 5 females (DZRJ).

Remarks. $P$. longispinata sp. nov. is closely related to $P$. tetravittata Flint, 1971 and P. trispicata Flint, 1971, which also occur in Amazonas State. The three species are similar in

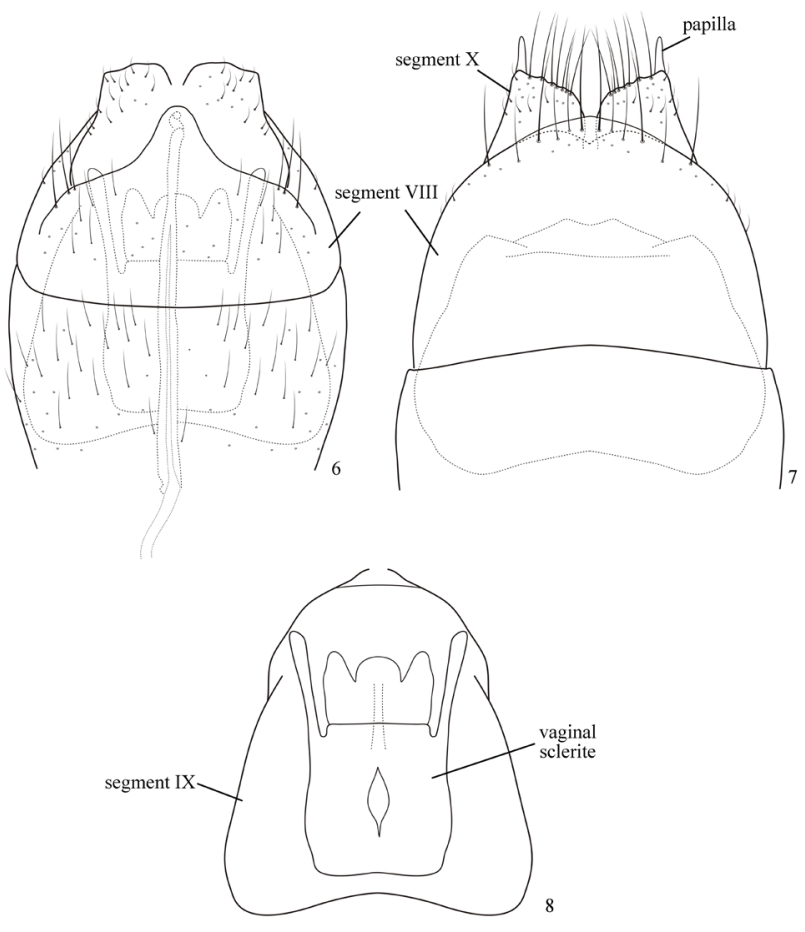

Figures 6-8 - Protoptila longispinata sp. nov.: 6. female genitalia, ventral view; 7. female genitalia, dorsal view; 8. vaginal sclerite and segment IX. Bar $=0.1 \mathrm{~mm}$.

lacking of lobate process on dorsum of phallus base, in having an upturned acute process on the anterior end of phallic apparatus, and in the sternum VIII broad and scooplike. $P$. longispinata differs from both $P$. tetravittata and $P$. trispicata in having only one pair of long pointed dorsolateral processes on the phallic apparatus, while these two species have two pairs. The new species also is distinguished from the $P$. tetravittata and $P$. trispicata by the broader segment $\mathrm{X}$ and by the acute processes on the posterolateral margins of sternum VIII.

Etymology. From Latin longi (long) and spina (spine), in allusion to the long dorsolateral processes of phallic apparatus.

\section{ACKNOWLEDGEMENTS}

We thank L. Fidelis and Dra. A.M.O. Pes (INPA) for field assistance. This study was supported by Fapeam, Fundação $\mathrm{O}$ Boticario, and CNPq. CAPES and CNPq provided fellowships, respectively, to A.P.M.S. and J.L.N. This is contribution number 00 of the Igarapés Project.

\section{LITERATURE CITED}

Flint, O.S., Jr. 1971. Studies of Neotropical caddisflies, XII: Rhyacophilidae, Glossosomatidae, Philopotamidae, and Psychomyiidae from the Amazon Basin (Trichoptera). Amazoniana, 3: 1-67.Holzenthal, R.W.; Blahnik, R.J. 2006. 
The caddisfly genus Protoptila in Costa Rica (Trichoptera: Glossosomatidae). Zootaxa, 1197: 1-37.

Paprocki, H.; Holzenthal, R.W; Blahnik, R.J. 2004. Checklist of the Trichoptera (Insecta) of Brazil I. Biota Neotropica, 4: 1-22.

Robertson, D.R.; Holzenthal, R.W. 2008. Two new species and a new record of Protoptila from Bolivia (Trichoptera: Glossomatidae: Protoptilinae). Annals of the Entomological Society of America, 101: 465-473.

Schmid, F. 1998. Genera of Trichoptera of Canada and adjoining or adjacent United States. NRC Research Press, Ottawa. 319 pp.

Recebido em 12/03/2009

Aceite em 22/04/2009 